DOI: 10.14526/2070-4798-2020-15-2-26-32

\title{
Tactical systems of the game transformation in modern football
}

\author{
Anatoliy A. Suchilin*, Mikhail A. Vershinin, Igor N. Novokshchenov \\ Volgograd State Academy of Physical Culture \\ Volgograd, Russia \\ ORCID: 00oo-0oo3-0926-9201, suchilin.anatolij@yandex.ru* \\ ORCID: oooo-Ooo1-7238-3491, vershinin mikhail7@rambler.ru \\ ORCID: oooo-ooo1-5322-0697,vgafk.fk@mail.ru
}

\begin{abstract}
Special literature analysis, which deals with the problem of training teams for Football World Championships (1958-2018) showed that within 6o years football had undergone considerable transformations in tactics, in spite of insignificant changes and additions in the rules of the game. Game tactics and tactical team formations are closely connected with the strategy. It means training and performance management of football team during the competitions. Training for the World Championships, the Olympic Games and other games is held owing to highly-qualified players in the coaching staff, financial and material support, taking into account the content of the group of preliminary stage of competitions and the final set aim. It is taking part in the final games. Taking into account all mentioned above facts tactical systems of game organization and the strategies of their use are chosen. However, there are no many scientific works connected with this topic or they are mainly about classical methodical approaches to players' training and tactical training development $[1,3,4,5,6]$. The World Championships and the Olympic Games, unlike National Championships, are held once in 4 years and have higher rating. They demand increased responsibility for the result from the state. It leads to the search for innovative systems of training football players for important competitions $[2,7,8]$. It is important to analyze modern tactics not only for professional football players, but also for theory and methodology development of football reserve training, especially at the stages of sports improvement (16-19 years old) and sportsmanship improvement (20-23 years old). Materials. Volga Olympic Academy as the base of the Olympic movement and the Olympic education development, Volgograd State Academy of Physical Culture as an educational complex in training highly-qualified football players and the specialists in football theory and methodology. Revealing tactical structures of football players from the National teams and their transformations at World Championships. Research methods. Methodical and scientific-methodical sources analysis and summarizing, complex, system and activity based approaches, pedagogical observation, interview, progressive practical experience summarizing. Results. We substantiated changes in modern tactical systems of the game among professional football players of the National teams. They took place within 60 years of world football development. We revealed four main tactical systems: Brazilian $(4+2+4)$, Spanish $(4+2+3+1)$, French $(4+5+1)$, Central European $(4+4+2)$. They depend on players selection ad can be transformed during the game depending on the result. Conclusion. The results, received during the research, help to suppose that the innovative approach to tactical structures of professional football teams, substantiate theoretical models of the systems. They can be used both in professional football and in training the Olympic reserve, youth teams.
\end{abstract}

Keywords: national and youth teams, complex, system and activity-based approaches, tactical systems, football, World Championship.

For citation: Anatoliy A. Suchilin*, Mikhail A. Vershinin, Igor N. Novokshchenov. Tactical systems of the game transformation in modern football. Russian Journal of Physical Education and Sport. 2020; 15(2): 23-27. DOI: 10.14526/2070-4798-2020-15-2-26-32

\section{INTRODUCTION}

Transformations in tactical systems in World football are conditioned by the complication of the demands claimed on physical development, functional, technical and tactical readiness, players' qualification and their sports achievements. They influence the choice of the definite system during training for World and Europe Championships, the Olympic Games. Tactical system of the game conditions the direction of football players' 
individual, group and team actions development $[9,10,11]$.

Tactical system of a football team choice is based on selection of players according to their role, their individual strong qualities use (high level of working capacity, original technique, well-placed shot, high speed of movement and etc.) and on the strategy of result achievement $[12,13,14,15]$.

Within 60 years period, after the triumphal victory of Brazil at the World Championship (1958). Brazil for the first time used tactical system $4+2+4$. We saw its transformation during each further Championship. There appeared other systems: $4+3+3,4+4+2,5+3+2$ and others.

The World Championship (2018) revealed innovative approaches to the choice of tactical systems by the leading football countries (France, Spain, Belgium and others). They once more improved tactical structures and functional duties of the players. It was the subject of the present research work, as the mentioned problem was not studied enough.

The aim of the research work was tactical structures creation among National teams football players and their transformation at World Championships. The following objectives were realized: to reveal the peculiarities of the professional football players' game systems, systems who showed spectacular game and high sports achievements; to reveal the influence of tactical structures on the achieved results.

During the research the following methods were used: methodical and scientific-methodical sources analysis and summarizing, complex, system and activity based approaches, pedagogical observation, interview, progressive practical experience summarizing.

\section{MATERIALS AND MATHODS}

As the methodology of the research we used complex, system and activity-based approaches (V.N. Platonov, A.A. Suchilin, S.Yu. Tyulenkov) [710]. They helped to consider t6actical structures of the teams as the system of the game with some peculiarities.

The scientists of Volga Olympic Academy and Volgograd State Academy of Physical Culture, specialists and coaches, who studied the dynamics of tactical structures of football players at World Championships, starting since 1958 (Sweden) and till 2018 (Russia) took part in the research. For this purpose the following primary sources were used: S.A. Savin, Yu.A. Morozov, V.I. Kozlovskiy and others, interview analysis with the outstanding coaches of the national teams of the USSR, Russia, Germany, Spain and etc. (K.I. Beskov, V.V. Lobanovskiy, N.P. Simonyan, S.S. Cherchesov, Yu. Klopp, Kh. Gvardiola and others) and football players of the national teams (A. Arshavin, V. Mostov and others), and video of the World Championships (TV and Internet). Gathered and analyzed material was periodically tested at the International and AllRussian scientific-practical conferences.

The presented material was received as a result of summarizing a great amount of information. It helped to make a retrospective journey into the history of football, following its methodologies and methods, substantiate tactical systems of football formation and development, starting from the end of the 50-s of the last century, when the old $\mathrm{W}(3+2+2+3)$ system was changed by "Brazilian" system $(4+2+4)$. It became the base for the world football.

In 1958 during the World Championship in Sweden the national team of Brazil surprised the Europeans by new tactical game structure, organizing the players according to a new system $(4+2+4)$. English W system. It was considered perfect one, turned out to have serious problems with defense. Three attacking W systems "faced" 4 protecting each other Brazilian full-backs and 4 forwards of Brazilian team got advantage over three W full-backs. The central part of the field didn't have considerable importance for highly-technical Brazilians. Their famous midfield organizer Didi passed with long passes to a quick wing Garrincha, center forward Vava and an outstanding 17- year old forward Pele. Brazilian football players showed the advantages of their system against straightforward tactics of W system in free zones of defenders. Brazil team won. Brazilian system of tactical structure became popular among all teams of the world.

Then Brazilian tactical system $(4+2+4)$ developed. There appeared its different 
modifications $(4+4+2),(4+3+3)$. With one forward destroying $(4+1+3)$ and back protecting defender $(1+4+3+2)$. With one $(4+1+3+2)$ and two supporting midfield players $(4+2+2+2)$, with the attacking central forward and supporting him back technical forward, who is able to organize and finish the attack. However, all these variants of tactical structures provided only functional duties redistribution among the players on a football field.

Brazilian system $(4+2+4)$ with its variants was used both with national teams and the leading clubs of Italy, Spain, England, Germany and other countries during more than 50 years.

The first features of innovative tactical transformation appeared in England and Germany, when club teams, such as "Manchester United", "Liverpool", "Bavaria" transferred to new structures according to $(4+2+3+1)$ system. Such organization of the players gave an opportunity to form powerful defensive redoubts from 6-9 football players and transfer to counterattack.

Professional football developed purposefully and quickly, especially in Europe. Talented players from all over the world came to powerful teams of Italy, Spain, England, Germany, France. It provided different tactical structures development. During national teams training for the World Championships coaches studied the experience, took achievements from club football, tried to use individual peculiarities of football players while defining the definite tactical system.

World Championship 2018 revealed three distinctive systems of training teams and game organization: Spain, Central European, French.

For Spain system it was typical to hold the ball mainly on the part of the opponent's field owing to short and average passes, "wall" passing, ball passing from side to side in terms of "free zones", an opponent dribbling in order to enter penalty area and the final actions: a shoot for goal, shooting the goal area, ball pass for the kick in order to goal. The main credo of Spain system was in the following: till the team had the ball, it had no reason to be afraid of the opponent, because it didn't have an opportunity to score the goal. It demanded performers selection. They had great physical conditions and functional abilities, demands change claimed on the players of all lines. Defending line formed two tall central defenders. They perfectly tackled the upper ball and didn't let anybody be the best in case of low combats. Grasping corner-backs managed to defend and take part in attacks. Midfield players were placed in the following way: first two players- base, physically fit, closer to central defenders - who controlled the base zone; slightly forward -three technical, creative players. They were the first to meet the attacking opponent and attacked with ball control or quick counterattack. A tall center forward was always at the top of the attack. He was able to finish passes, more often using heading.

Tactics of Spaniards was formed owing to technical, quick football players selection, their interchangeability near the opponent's goal and it constantly formed a range of objectives for the defending team. The advantage of tactical structure of Spanish team game was in the following: masterful ball tackling owing to "pass culture", precise passes and ball serving, constant movement of players along the whole attacking area; strict game discipline. The drawbacks of this tactics were the following: great energy expenditure of the players. It lead to tiredness at the end of the game, especially in case of extra period; danger of opponent's counterattacks, who got an opportunity to play at a great area. Mentioned above drawbacks didn't let team from Spain become the leader of the World Championship, but it showed spectacular, nice game.

Central European system $(4+4+2)$, which was demonstrated by the teams from Croatia, Belgium, England and Sweden, showed wellorganized game using the strongest qualities of the experienced football players. They were acknowledged by the best Spanish, English and Italian professional teams ("Real", "Barcelona", "Manchester United", "Manchester City", "Juventus", "Milan" and others). The system of the game was mainly similar to French one: ball holding mainly on own part of the field, owing to short and average passes, quick counterattacks organized, as a rule, by creative football players with a good kick (L. Modric, I. Rakitic, M. Fellaini).

The advantage of football players of Croatia and Belgium over other teams was in psychological 
aiming at the victory, in more intensive moor activity and game activity in comparison with the opponents, in accuracy of the fulfilled free, penalty and corner kicks. The game of the team from England should be especially defined, as it had a powerful staff with great amount of young football players. They showed French system with English accent $(4+2+3+1)$ with the outstanding center forward Harry Kane. However, it was seen that the team lacked experience and the powers of young football players decreased during the final stage of the championship. The team lost the game and didn't get the $3^{\text {rd }}$ place (Belgium took the $3^{\text {rd }}$ place).

French system had a combined character. Clear defense, which included 2 lines: 4 defenders and 4 halfbacks with two basic (Paul Pogba and N'Golo Kanté) and two forwards (tall, strong Olivier Giroud and creative, quick, not very tall Antoine Griezmann). The team from France in most matches closed its goal and had a sharp counterattack in terms of free zones of the opponent (owing to young gifted player, who was quick and enduring, powerful halfback Kylian Mbappé). In the situations when there were no "free zones" on the opponent's field, Frenchmen started to attack. Frenchmen inclusion into the attack was according to Spanish plan: cornerbacks took part in the situations with free, penalty and corner kicks tackling. The main French system $(4+4+2)$ transformed into dependence on the game result: during the defense into the system 5 in a line $(5+4+1)$, during the attack $-(3+5+2)$, occasionally- $(3+2+5)$.

The advantage of French system over Spanish one, which let Frenchmen win the World Championship 2018, was in quicker transfers from defense to attack and from the attack to defense. They were fulfilled with the help of highly-qualified halfbacks and individually strong leader Antoine Griezmann.

\section{CONCLUSION}

The games analysis during the World Championship-2018 in Russia showed considerable transformation of Brazilian system in world football within last 60 years.

1. "Brazilian tactical system" $(4+2+4)$ created the base for innovative variants of the game: $(4+2+3+1)$,
$(4+5+1),(4+4+2)$. They were formed into "Spanish", "Central European" and "French" systems. System choice and tactical actions realization depended on the set before the team aim, quality of the players' role and the rating of the opponent.

"Spanish tactical system" $(4+2+3+1)$ demands highly-technical, physically strong players selection with high functional abilities at all lines and parts and is realized owing to ball holding, opponent attach with accurate short and average passes, the final kick fulfillment from the penalty area of the opponent. Its advantage is the following: own goal safety owing to a long-term ball possession (more than $80 \%$ of the game time). Its drawbacks are the following: danger of a mistake during the ball loss and quick counterattacks of the opponent with a goal kick without any obstacles.

"Central European" (4+4+2) system combines the elements of "Spanish" and "French" systems, it is based on well-planned defense with quick counterattack owing to long passes and in terms of its slow down owing to transfer to positional attack using short and average passes; kicks from far distances or shots along the opponent's goal.

For "French system" $(4+5+1)$ it is typical to select physically strong defenders and halfbacks in order to get free from constant struggle of a creative football player in the attacking line; game of the defense from two echelons: defenders and halfbacks, timely transfer of the players of this role into "their zones"; pressure during the ball loss; constructive game of a creative forward; quick attack development owing to quick halfbacks. Drawbacks of the system: quick counterattacks with the final kicks and the prepared during the training sessions standard combinations, which lead to the goal.

During professional teams training for competitions any of three innovative systems can be used ("Spanish", "Central European", "French") depending on the aim, players selection, the training level of the players, strategy at the definite tournament and during the definite match.

Substantiated by us systems of tactical structures, which appeared in world football during the happening transformations, can be theoretical models for training professional national and youth teams for International football competitions.

\section{REFERENCES}

1. Ali A., Williams C., Hulse M., Strudwick A., Reddin J., Howarth L., et al. Reliability and validity of two tests of soccer skill. Journal of Sports Sciences. 2007; 25: 1-10.

2. Anatoly A. Suchilin, Igor N. Novokshchenov. Innovative approach to the methodology of players' physical fitness improvement in indoor soccer. 2018; 13(1): 46-52. DOI: 10/14526/01_2018_282 
[In Russ., In Engl.].

3. Zheney E. Tendencies in modern world football and their reflection in the training process. Metodika podgotovki zarubezhnyh sportsmenov. 1985; 6: 4045 [In Russ.].

4. Lobanovskiy V. V., Razumovskiy E.A. Technikotakticheskie dejstviya futbolistov [Technicaltactical actions of football players]. Moscow: Physical culture and sport. 2007: 245 [In Russ.].

5. Matvienko A. I. Developing the structure of tactical actions of the players from professional football clubs in competitive process. Vestnik Polotskogo gosudarstvennogo universiteta. 2013; 7: 165-170. URL: http://elib.psu.by:8080/ handle/123456789/995 [In Russ.].

6. Morozov Yu., Beskov K. Analiz technikotakticheskoj deyatel'nosti futbolistov na $X$ chempionate mira [Technical-tactical activity analysis of football players at the $\mathrm{X}$ World Championship. Training football players]. Moscow: Physical culture and sport. 1977: 134155 [In Russ.]. URL: http://nashaucheba.ru/ v55570/козловский в.и. ред. подготовка футболистов?page $=9$.

7. Di Salvo V., Baron R., Tschan H., Calderon Montero F.J., Bachl N., Pigozzi F. Performance characteristics according to playing position in elite soccer. International Journal of Sports Medicine. 2007; 28: 222-227.

8. Suchilin A.A. Innovative approach to model characteristics creation among professional football players. Teoriya I praktika fizicheskoj kul'tury = Theory and practice of physical culture. - Moscow, 2016: 11-14 [In Russ., In Engl.].

9. Suchilin A.A. Teoretiko-metodologicheskie pokazateli igry I factory effektivnosti sorevnovatel'noj deyatel'nosti $v$ futbole: monografiya [Theoretical-methodological basis of training the reserve for professional football : monograph]. Volgograd: VSAPC. 1997: 237 [In Russ.].
10. Tyulenkov S.Yu. Structure of technical-tactical game indices and the factors of competitive activity effectiveness in football. Tendencii razvitiya sporta vysshih dostizhenij I strategiya podgotovki vysokokvalificirovanny sportsmenov $v$ 1997-20oogg.: materialy Vserossijskoj nauchno-prakticheskoj konferencii [Tendencies of professional sport development and the strategy of training highly-qualified athletes in 19972000: materials of All-Russian scientific-practical conference]. Moscow. 1997: 386-395 [In Russ.].

11. Football World Championship 2018 (content). URL: https://ru.wikipedia.org/wiki/.

12. Football World Championship -2018: All groups, tables, results of matches. URL: http:// allprofootball.ru

13. Figueiredo A.J., Goncalves C.E., Coelho E Silva M.J., Malina R.M. Characteristics of youth soccer players who drop out, persist or move up. Journal of Sport Sciences. 2009; 27: 883-891.

14. Gil S., Ruiz F., Irazusta A., Gil J., Irazusta J. Selection of young soccer players in terms of anthropometric and physiological factors. Journal of Sports Medicine and Physical Fitness. 2007; 47: 25-32.

15. Hosseinikhezri S.A., Zakharova A.B. The consideration of foot posture index in Russian soccer players 10-12 years-old. Pedagogikopsihologicheskie I medico-biologicheskie problemy fizicheskoj kul'tury I sporta = The Russian Journal of Physical Education and Sport. 2018; 13(1): 172177. DOI: 10/14526/01_2018_297 [In Russ., In Engl.].

\section{Submitted: 10.06.2020}

\section{Author's information:}

Anatoliy A. Suchilin - Doctor of Pedagogics, Professor, Volgograd State Academy of Physical culture, 400oo5, Russia, Volgograd prospect named after V.I. Lenin, House 78, e-mail: suchilin.anatolij@ yandex.ru

Mikhail A. Vershinin - Doctor of Pedagogics, Professor, Volgograd State Academy of Physical culture, 400oo5, Russia, Volgograd prospect named after V.I. Lenin, House 78, e-mail: vershinin mikhail7@ rambler.ru

Igor N. Novokshchenov - Candidate of Pedagogics, Associate Professor, Volgograd State Academy of Physical culture, 400005, Russia, Volgograd prospect named after V.I. Lenin, House 78, e-mail: vgafk. fk@mail.ru 